\title{
MLL/AFF1 Fusion Protein
}

National Cancer Institute

\section{Source}

National Cancer Institute. MLL/AFF1 Fusion Protein. NCI Thesaurus. Code C99320.

A fusion protein ( 2250 aa, $240 \mathrm{kDa}$ ) encoded by the MLL/AFF1 fusion gene. This protein is comprised of the $\mathrm{N}$-terminal half of the histone-lysine $\mathrm{N}$-methyltransferase MLL protein, including the AT hook DNA binding domain and the DNA methyltransferase domain, fused to the C-terminal half of the AF4/FMR2 family member 1 protein. 